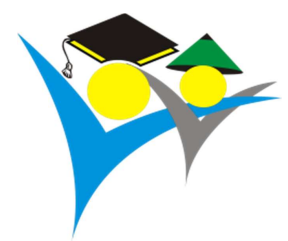

\title{
Inovasi Biopestisida Melalui Program Pengembangan Usaha Produk Intelektual Kampus Di UPT Agroteknopark Universitas Jember
}

\author{
Hari Purnomo $^{1 *}$, Nanang Tri Haryadir ${ }^{1}$, Usmadi $^{2}$, Hadi Paramur ${ }^{3}$ \\ I(Program Studi Agroteknologi, Universitas Jember, Jember - Indonesia; \\ ${ }^{2}$ (UPT Agrotenopark, Universitas Jember, Jember - Indonesia; \\ ${ }^{3}$ (Program Studi manajemen, Universitas Jember, Jember - Indonesia.
}

\author{
Article history \\ Received: 23 November 2021 \\ Revised: 30 November 2021 \\ Accepted: 15 Desember 2021 \\ *Corresponding Author: \\ Hari Purnomo \\ Program Studi Agroteknologi, \\ Universitas Jember, Jember - \\ Indonesia \\ Email: \\ haripurnomo.faperta@unej.ac.id
}

Abstract: Management of agricultural cultivation has shifted from conventional cultivation management to management of good agriculture practices. One of the efforts to overcome the obstacles in managing plant pest organisms in good agricultural management practices is to minimize the application of the use of inorganic chemical pesticides that do not have an impact on environmental health but also have an impact on the health of user farmers. Biopesticide is an environmentally friendly alternative, which is a pesticide with active ingredients of insect pathogenic microbes such as Beauverisa bassiana and Metarhizium anisopliae. Research development of insect pathogenic fungi in the Agroecotechnology laboratory of the Faculty of Agriculture, University of Jember entered the downstream scale-up stage after having a Prototipe biopesticide with an active ingredient of insect pathogenic fungi with a pure fungal mycelia flour formulation which is currently in the process of brand licensing and draft patents. Activities in this program are aimed at: 1) developing a biopesticide production unit (from production to packaging) with limited marketing to farmers in LP2M assisted villages but still profitable, 2) aiming to build a marketing network for biopesticide products to wider stakeholders in the Besuki Raya area, and 3) strengthening the institutional unit of biopesticide production into a larger industry.

Keywords: bacteria; fungi; environment; organism; insect

Abstrak: Pengelolaan budidaya pertanian telah bergeser dari pengelolaan budidaya konvensional menuju pengelolaan yang menerapkan praktek budidaya yang baik (good agriculture practices). Salah satu upaya mengatasi kendala pengelolaan organisme pengganggu tanaman dalam praktek pengelolaan pertanian yang baik adalah meminimalisasikan aplikasi penggunaan pestisida kimia anorganik yang tidak berdampak pada kesehatan lingkungan akan tetapi juga berdampak pada kesehatan petani pengguna. Biopestisida adalah salah satu alternatif yang ramah lingkungan merupakan pestisida berbahan aktif mikroba pathogen serangga seperti Beauverisa bassiana dan Metarhizium anisopliae. Pengembangan riset jamur pathogen serangga yang ada di laboratorium Agroekoteknologi Fakultas Pertanian Universitas Jember memasuki tahapan scale up hilirisasi setelah mempunyai prototipe biopestisida berbahan aktif jamur pathogen serangga dengan formulasi tepung murni miselia jamur yang sedang dalam proses izin merk dan draft paten. Kegiatan dalam program ini bertujuan: 1) Untuk mengembangkan unit produksi biopestisida (mulai produksi sampai pengemasan) dengan pemasaran terbatas pada petani pada desa binaan LP2M tapi tetap profitabel, 2) Bertujuan untuk membangun jejaring pemasaran produk biopestisida pada stake holder yang lebih luas dalam wilayah Besuki Raya, dan 3) Memantapkan kelembagaan unit produksi biopestisida menjadi industri lebih besar.

Kata kunci: bakteri; jamur; lingkungan; organisme; serangga 


\section{PENDAHULUAN}

Unit pelaksana teknis (UPT) Agroteknopark Universitas Jember telah dirintis sejak tahun 2006 berupa rintisan kebun-kebun koleksi bibit tanaman yang pada awalnya digunakan untuk mendukung proses pembelajaran di lingkungan Universitas Jember dan dikelola oleh suatu panitia yang bertanggung jawab kepada Rektor hingga menjelang 2011. Berdasarkan SK Rektor Universitas Jember 1228/H.25/TU.2/ 2011 tanggal 2 November 2011, status kelembagaan ditingkatkan menjadi Unit Pengelola Teknis (UPT) dengan nama UPT Agroteknopark dan dalam OTK yang baru telah juga disahkan oleh Permenristekdikti No. 16/2016 tentang SOTK Universitas Jember.

UPT Agroteknopark pada saat ini telah mengelola selain kebun-kebun koleksi bibit tanaman di kampus Tegal Boto juga mengelola kebunAgroteknopark seluas 14 ha di desa Jubung, Kecamatan Sukorambi, Kabupaten Jember. Kebun di Kampus Tegal Boto mempunyai kebun buah naga dan beberapa buah langka, kebun jeruk, kebun sayuran, kebun anggrek dan unit pengelolaan sampah kampus untuk dikelola menjadi sampah organik. Di Kebun Agroteknopark di desa Jubung seluas 14 hektar digunakan untuk lahan padi, lahan kedelai edamame dan okra yang bekerja sama dengan PT Mitra Tani 27, taman boga, pabrik air mineral Aeng dan minuman herbal yang semua hasil menjadi PNBP Universitas Jember karena masih satker. Peranan UPT Agroteknopark sebagai unit penghasil RG Universitas Jember (Tabel 1) tetap tidak menyampingkan tupoksi utamanya sebagai pendukung proses pembelajaran di lingkungan Universitas Jember yaitu penelitian dan praktikum.

Tabel 1.

Target RGA tahun 2018 UPT Agroteknopark Universitas Jember

\begin{tabular}{lcccc}
\hline \multicolumn{1}{c}{ Indikator kinerja } & Tahun 2017 & \multicolumn{2}{c}{ Tahun 2018 } & Capaian \\
\hline & & Target & capaian & \\
\hline $\begin{array}{l}\text { Revenue Generating } \\
\text { Activities (RGA) }\end{array}$ & 185.000 .000 & 150.000 .000 & 154383.500 & Menurun 13.8\% \\
\hline Produk AMDK & 4.073 & 4500 & 5278 & Meningkat 29.6\%) \\
\hline Produk bibit & & 10000 & 9534 & \\
\hline
\end{tabular}

Status Universitas Jember yang masih satker menjadi kendala utama dalam pengembangan UPT menjadi unit penghasil RG utama, banyak kesulitan yang dihadapi ketika masih satker yaitu terbatasinya pemasaran hasil produk UPT karena legalitas untuk pemasaran masih terhambat oleh administrasi perizinan izin edar dan izin pemasaran karena sebagai satker UPT tidak berbadan hukum yang mempunyai SIUPP, sehingga selama ini semua RG yang dihasilkan oleh UPT Agroteknopark masih belum dijual di luar Universitas Jember dan masih menjadi konsumsi kebutuhan internal. Sebagai contoh unit pabrik air minum mineral dan herbal dalam kemasan digunakan untuk melayani kebutuhan internal di UNEJ, penjualan buah-buahan dan sayuran masih hanya bias dipromosikan secara internal pada aktivitas akademika UNEJ, Unit pengelolaan sampah dalam bentuk kompos hanya digunakan untuk memenuhi kebutuhan pemupukan di areal kampus yang membutuhkan dan kebutuhan penelitian dosen dan mahasiswa, unit biopestisida dan biofertilizer yang sudah memproduksi biopestisida terhambat dalam perizinan izin edar dari kementan meskipun sudah proses izin merk di kemnhumkam. Kendala-kendala ini akan teratasi manakala Universitas Jember berstatus badan Layanan Umum (BLU) yang sudah mendapatkan persetujuan menunngu keputusan yang diperkirakan tahun 2019 akan menjadi BLU.

UPT Agroteknopark sebagai Hub hilirisasi hasil riset berupa Prototipe telah mendapatkan dukungan yang besar dari program loan Islamic Development bank, sehingga pada semester 1 tahun 2020, maka Kebun Agroteknologi di desa Jubung akan menjadi Scicence park science park technology yang mempunyai sarana prasarana, gedung/plaza pameran hasil riset dan hilirisasiri aktivitas akademika UNEJ, gedung pelatihan untuk Inkubator dan dormatorinya, pabrik air minum dan herbal dalam kemasan yang representatif, unit uji terbatas hilirisasi produk rekayasa genetic seluas 2 ha, dan yang menjadi pendukung program PPUPIK adalah dibangunnya pabrik biopestisida dan biofertilizer seluas $1000 \mathrm{~m}^{2}$ (http://piu-idbproject.unej.ac.id/).

Prototipe biopestisida yang telah dikembangkan oleh ketua pengusul yaitu Prototipe biopestisida dengan tingkat kesiapan teknologi 5 merupakan serangkaian riset pengusul sejak tahun 1992 sampai sekarang yang dimulai dari penelitian dasar berupa eksplorasi, isolasi dan uji biologis terhadap jamur patogen serangga yang ditemukan 
sampai penelitian terapan hibah bersaing dan stranas melalui hibah komptesi DRPM dan juga melalui KKP3T dan KKP3N kerja sama dengan Badan Penelitian dan Pengembangan Pertanian Kementrian Pertanian dan pada tahun 2018 mendapatkan pendanaan calon pengusaha pemula berbasis teknologi (CPPBT) dan hasilnya berupa Prototipe biopestisida berbahan aktif formulasi tepung murni miselia.

Produk sejenis biopestisida berbahan aktif jamur patogen serangga telah ada beberapa di pasaran, seperti produk Nasa dan beberapa produk yang sama yang diproduksi oleh laboratorium-laboratorium penyedia agens hayati yang dikelola oleh beberapa gapoktan. Keunggulan Prototipe dengan produk biopestisida sejenis adalah: 1). isolat yang dijadikan bahan aktif merupakan isolat terpilih dari beberapa isolat jamur dan telah melalui uji efikasi di laboratorium dan lapang pertanaman sesungguhnya sehingga didapatkan isolat yang virulen dan menunjukkan hasil rekam jejak riset yang konsisten, 2). formulasi tepung murni miselia merupakan formulasi pertama yang dihasilkan dari riset ini, dimana produk lain formulasinya merupakan formulasi tepung tidak murni masih tercampur dengan media padat jagungnya sehingga jika diaplikasikan dengan menggunakan sprayer standar akan menyebabkan penyumbatan nozzel, kalau formulasi tepung murni akan dissolve dalam air secara sempurna tanpa menyebabkan terjadinya penyumbatan, 3). Produksi biopestisida menggunakan sistem 2 fase yaitu fase kultur cair dan fase kultur padat yang akan meningkatkan produksi konidia sebesar $2 \times 10^{8} \mathrm{cfu} / \mathrm{gram}$ yang memenuhi standar SNI dan uji coba menunjukkan kemampuan membunuh wereng, walang sangit, bubuk buah kopi, uret tebu mencapai 85-95\%.

Produk biopestisida yang akan diproduksi merupakan formulasi tepung miselia murni. Produk ini dihasilkan dengan menggunakan 3 fase sistem, dimana fase kultur cair adalah fase pertumbuhan kultur jamur pada fermentor (alat akan dipatenkan sederhana) selama 7 hari dengan pengadukan kontinu, kemudian kultur cair ditumbuhkan pada media beras jagung yang telah disterilkan dan akan tumbuh merata setelah 10 hari, setelah itu dilakukan proses pengeringan dan kemudian dengan alat separator yang kami rancang, maka tepung murni miselia dan beras jagung akan terpisah, kemudian dikemas.

Produk biopestisida yang akan diproduksi adalah berbahan aktif jamur Beauveria bassiana dan Metarhizium anisopliae, dimana hama sasaran dari B. bassiana adalah wereng coklat dan hijau, walang sangit, kutu-kutuan, dan ulat pemakan daun, sedangkan $M$. anisopliae lebih digunakan untuk hama sasaran yang menyerang akar tanaman seperti uret (larva kumbang), ulat tanah pemotong akar. Dengan spesifikasi sasaran berbeda diharapkan kedua biopestsida mampu menyelesaikan pengelolaan OPT di tanaman padi, kedelai, jagung, tebu, singkong dan sayuran yang menjadi tanaman utama yang sering dibudidayakan di daerah Besuki Raya (Jember, Banyuwangi, Bondowoso, Lumajang, Situbondo, dan Probolinggo). Produk biopestisida dikemas dalam kemasan sachet $100 \mathrm{~g}$ dengan nama BEBAS (B. bassiana) dan METAR (M. Anisopliae). Dosis rekomendasi yang dianjurkan untuk pengelolaan OPT adalah $25 \mathrm{~g}$ per 14 liter air dalam sprayer.

Prototipe biopestisida juga telah mendapatkan dana atau grant on going untuk pendaftaran paten secara internal Universitas Jember (Hibah HKI 2019) sehingga draft paten sedang diselesaikan untuk memenuhi syarat patent di kemenkumham, meskipun demikian pendaftaran merk biopestisida telah dilaksanakan meskipun belum granted pada awal tahun 2019 dengan nomor permohonan DID2019001774 untuk BEBAS dan DID2019001924 untuk METAR.

Biopestisida berbahan aktif jamur patogen serangga yang sudah dibuktikan tidak memberikan dampak negatif baik bagi agroekosistem (tanaman, serangga berguna) dan petani tapi efektif mengendalikan serangga hama sasaran, akan menjadi salah satua alternatif untuk mengurangi dampak penggunaan pestisida kimia sintetik yang sekarang telah menjadi taktik pengendalian andalan bagi petani meskipun berdampak negatif bagi lingkungan dan menimbulkan terjadi resurgensi (kematian musuh alami), resistensi hama sasaran dan menimbulkan munculnya serangan hama kedua. Pada akhirnya penggunaan biopestisida ini akan menghasilkan produk pertanian yang sehat yang mampu meningkatkan kualitas hidup masyarakat yang pada akhirnya berdampak pada sumberdaya manusia yang sehat, unggul dan berdaya saing tinggi karena mengkonsumsi produk pertanian yang sehat. Adapun tujuan kegiatan ini meliputi a) Pengembangan unit produksi produk biopestisida dengan bahan aktif jamur patogen serangga Beauveria bassiana dan Metarhizium anisopliae dengan formulitas tepung murni konidia udara (aerial conidia) di UPT Agroteknopark Universitas Jember; dan b) Pengembangan pusat penyedia produk Agens Pengendali Hayati (PPAPH) dengan pilot project biopestisida jamur patogen serangga di UPT Agroteknopark Universitas Jember. Sedangkan sasaran kegiatan adalah a) Pemberdayaan masyarakat petani untuk menggunakan 
bahan-bahan alami dalam upaya mengurangi penggunaan pestisida sintetik; dan b) Memperluas jejaring antara masyarakat petani dan UPT Agroteknopark.

\section{METODE}

Beberapa kegiatan yang dapat diuraikan dalam rangka pemberdayaan masyarakat petani untuk menggunakan bahan bahan alami dalam upaya mengurangi penggunaan pestisida sintetik; dan sekaligus memperluas jejaring antara masyarakat petani dan UPT Agroteknopark, adalah sebagai berikut:

\section{Teknik Produksi Biopestisida jamur patogen serangga formulasi tepung konidia}

\section{Pembuatan Media SDAY (Sabouraud Dextrose Agar Yeast)}

a. Menimbang media SDA sebanyak 65 gram dan Yeast.

b. sebanyak 2 gram menggunakan timbangan analytic.

c. Masukkan ke dalam erlenmeyer dan menambahkan aquadest hingga $1000 \mathrm{ml}$ dan mengaduknya menggunakan spatula.

d. Memasak media tersebut di atas kompor kurang lebih setengah jam dan mengaduknya hingga media tersebut homogen dan tambah lebih bening.

e. Media yang sudah dimasak kemudian disterilkan menggunakan autoclave selama 15 menit dengan suhu $121^{\circ} \mathrm{C}$ bertekanan $15 \mathrm{~atm}$.

f. Setelah media tersebut disterilkan, maka media telah siap untuk digunakan.

g. Pemberian Clorampenicol untuk anti bakteri dengan takaran setengah sendok teh pada saat media sudah hangat kuku.

h. Plating media SDAY ke petridisk sebanyak $10 \mathrm{ml}$ secara aseptis di LAF (Laminer Air Flow).

\section{Perbanyakan Isolat Beauveria bassiana dan Metarhizium anisopliae}

a. Siapkan semua peralatan dan bahan untuk proses peremajaan, masukkan semua peralatan dan bahan pada LAF steril.

b. Lakukan proses peremajaan dengan cara memindah miselium atau cendawan dari kultur yang sudah tua menggunakan jarum ent/ose steril, pindah pada media SDAY yang baru secara aseptis.

c. Inkubasi selama 10-15 hari sampai cendawan tumbuh memenuhi petridisk.

\section{Pembuatan Biang Medium Cair}

a. Bahan biang medium cair dalam 1 liter air.

* Aquadest steril 1 liter, Glukosa 40 g., $\mathrm{KNO}_{3} 10$ g., $\mathrm{KH}_{2} \mathrm{PO}_{4} 5$ g., $\mathrm{MgSO}_{4} 2$ g., Yeast Ekstrak 2 g., Antibiotik Tetracycline $\mathrm{HCl} 0,05$ g. dan $\mathrm{NaOH}$ (bila diperlukan).

* $10 \mathrm{ml}$. Cendawan (hasil panen dari 1 petridish dengan $10 \mathrm{ml}$ aquadest + tween 0,05\% steril).

b. Mencampur bahan kering dan ditambah dengan aquadest steril aduk hingga homogen.

c. Masak media di atas tungku atau hotplate hingga medium cair homogen.

d. Melakukan pengecekan kadar $\mathrm{pH}$ larutan ( $\mathrm{pH}$ harus berkisar 7-8), tambahkan $\mathrm{NaoH}$ bila $\mathrm{pH}$ larutan rendah hingga mencapai $\mathrm{pH}$ yang diinginkan.

e. Melakukan sterilisasi medium cair menggunakan autoclave.

f. Melakukan sterilisasi erlenmeyer untuk fermentor menggunakan autoclave, dan melakukan perebusan selang yang akan digunakan untuk fermentasi.

g. Memindahkan medium cair ke erlenmeyer secara aseptis (dalam laminair air flow).

h. Membiarkan medium cair dingin.

i. Melakukan inokulasi cendawan ke dalam medium cair dengan cara aseptis di dalam laminair air flow.

j. Melakukan fermentasi menggunakan fermentor selama 5-7 hari. 


\section{Pembuatan Medium Cair}

a. Melakukan sterilisasi dandang (wadah pencampuran/pembuatan medium cair) dengan cara dicuci menggunakan desinfektan, dikeringkan dan direbus dengan air panas 20 menit, kemudian disemprot dengan alkohol.

b. Melakukan sterilisasi galon/tangki untuk fermentor menggunakan uap panas, dan melakukan perebusan selang yang akan digunakan untuk fermentasi menggunakan fermentor.

c. Bahan medium cair dalam 1 liter air: Aquadest steril 1 liter, Glukosa 40 g., $\mathrm{KNO}_{3} 10$ g., $\mathrm{KH}_{2} \mathrm{PO}_{4} 5 \mathrm{~g}, \mathrm{MgSO}_{4}$ 2 g., Yeast Ekstrak 2 g., Antibiotik Tetracycline $\mathrm{HCl}$ 0,05 g. dan NaoH (bila diperlukan).

d. Mencampur bahan kering dan ditambah dengan aquadest steril aduk hingga homogen.

e. Masak media di atas tungku hingga medium cair homogen.

f. Melakukan pengecekan kadar $\mathrm{pH}$ larutan ( $\mathrm{pH}$ harus berkisar 7-8), tambahkan $\mathrm{NaoH}$ bila $\mathrm{pH}$ larutan rendah hingga mencapai $\mathrm{pH}$ yang diinginkan.

g. Menutup dandang setelah kadar $\mathrm{pH}$ sesuai hingga medium mendidih, dan biarkan tetap dipanaskan di atas tungku hingga 20 menit.

h. Melakukan pemindahan medium cair ke dalam drum fermentor yang telah disterilisasi sebelumnya saat media masih panas dan baru diangkat dari tungku untuk menghindari adanya kontaminasi lalu tutup dengan rapat drum.

i. Mendiamkan medium cair dalam drum hingga dingin, sementara dengan melakukan sterilisasi pompa air dengan cara dialiri air panas selama 15 menit kemudian dialiri alkohol selama 5 menit.

j. Memindahkan biang medium cair ke dalam tangki atau drum fermentor yang telah diisi dengan medium cair secara aseptis dengan menggunakan pompa air setelah medium cair dingin.

k. Membiarkan medium cair dingin.

1. Melakukan pemasangan selang-selang yang terhubung dari fermentor ke drum dan drum ke enlenmeyer berisi aquadest steril.

m. Melakukan fermentasi menggunakan fermentor selama 7-10 hari.

\section{Pemanenan Medium Cair}

a. Melakukan persiapan alat yang akan digunakan untuk proses pemanenan

i. Melakukan sterilisasi dandang (wadah panen) dengan cara dicuci menggunakan desinfektan, dikeringkan dan direbus dengan air panas hingga mendidih 30 menit, kemudian disemprot dengan alkohol.

ii. Melakukan sterilisasi saringan, loyang dan kain saring dengan cara dicuci menggunakan desinfektan kemudian dikeringkan.

iii. Loyang yang telah dicuci kemudian direndam dengan air panas selama 30 menit, kemudian disemprot dengan alkohol.

iv. Saringan dan kain saring yang telah kering disterilkan kembali dengan diautoclave, dan sebelum digunakan disemprot alkohol.

v. Melakukan sterilisasi pompa air dengan cara dialiri air panas selama 15 menit kemudian dialiri alkohol selama 5 menit.

vi. Melakukan sterilisasi botol ukuran 1 liter dengan diuapkan selama 1 menit.

b. Melakukan pemanenan medium cair dengan menggunakan pompa air steril ke dalam dandang/wadah pemanenan yang telah diberi saringan dan kertas saring.

c. Medium cair yang telah diperoleh dimasukkan ke dalam botol ukuran 1 liter sebanyak $900 \mathrm{ml}$ dan ditutup rapat, kemudian dilakukan penyimpanan pada suhu ruang dan lemari es.

\section{Membuat Media Padat (Beras Jagung)}

a. Beras jagung dicuci dengan air mengalir sampai bersih.

b. Rendam beras jagung yang sudah bersih dengan air aquades steril selama 2 jam.

c. Setelah cukup 2 jam tiriskan sampai bersih, dan setelah itu masukkan jagung ke dalam kantong plastik tahan panas sebanyak 100 gram per kantong dan tambahkan minyak sayur atau minyak goreng sebanyak $10 \mathrm{ml} / \mathrm{kg}$ beras jagung. 
d. Sterilkan beras jagung yang sudah ditimbang di dalam autoclave selama 15 menit dengan suhu $121^{\circ} \mathrm{C}$. Setelah disterilkan, buka autoclave dan biarkan media beras jagung sampai dingin.

e. Media pada beras jagung siap digunakan.

\section{Perbanyakan Isolat pada Media Padat (Beras Jagung)}

a. Siapkan media beras jagung 100 gram dalam plastik yang steril.

b. Siapkan bahan dan alat lain yang digunakan di dalam LAF yang sudah steril.

c. Buka media beras jagung yang dibungkus plastik tahan panas dan hancurkan gumpalan beras jagung yang menyatu dengan cara diremas-remas.

d. Inokulasi kultur cair cendawan entomopatogen pada media beras jagung sebanyak $2 \mathrm{ml} / 100$ gram media beras jagung, kemudian dikocok-kocok dan ratakan hingga tidak terdapat udara di dalamnya.

e. Bagian ujung plastik yang terbuka distaples, kemudian diberi label.

f. Lakukan kegiatan ini secara aseptis untuk menghindari kontaminasi.

g. Lakukan inkubasi di tempat yang steril selama 14 hari sampai beras jagung tertutupi oleh miselium cendawan entomopatogen.

\section{Pengeringan Isolat pada Media Padat}

Kemasan beras jagung yang siap dilakukan proses pengeringan yaitu beras jagung yang tertutupi oleh miselium cendawan. Bila itu Beauveria bassiana miseliumnya berwarna putih sedangkan Metarhizium anisopliae berwarna putih semakin lama berubah menjadi hijau.

a. Menyiapkan kemasan media padat yang siap untuk dikeringkan dan kertas pengeringan.

b. Memindahkan beras jagung yang ada pada kemasan ke kertas pengeringan lalu diinkubasi selama 14 hari.

\section{Pemanenan Isolat pada Media Padat}

a. Siapkan alat penggilingan, alat pres, timbangan, wadah kemasan, dan label kemasan.

b. Lakukan penggilingan media padat yang telah dikeringkan.

c. Hasil penggilingan akan terpisah antara bubuk cendawan dan beras jagung.

d. Timbang bubuk yang diperoleh lalu kemas dan beri label.

\section{Aplikasi ke Serangga Hama}

a. Aturan pakai formulasi bubuk yaitu larutkan 50g biopestisida ke dalam tangki 14 liter knapsack sprayer. Aturan pakai formulasi cair yaitu larutkan 3cc biopestisida ke dalam 1 liter air.

b. Lalu semprotkan pagi atau sore hari.

c. Amati efek aplikasi terhadap hama sasaran yang menunjukkan gejala mumi berwarna putih untuk Beauveria bassiana sedangkan putih kemudian berubah hijau untuk Metarhizium anisopliae.

Keluaran yang dihasilkan dalam kegiatan ini adalah sebanyak $50 \mathrm{~kg}$ biopestisida jamur patogen serangga dengan bahan aktif jamur $B$. bassiana dan M. anispliae yang telah dikemas dalam kemasan aluminium foil terlabel dengan isi $100 \mathrm{~g}$ tepung konidia. Sebanyak $20 \mathrm{~kg}$ media jagung yang telah diinokulasi dengan jamur patogen serangga dan sedang diinkubasi setelah diinokulasi dengan medai isolat jamur patogen serangga.

\section{Deskripsi Biopestisida berbahan aktif Jamur Patogen Serangga}

Biopestisida berbahan aktif jamur patogen serangga merupakan biopestisida yang diproduksi dengan menggunakan teknik dua fase, dimana teknik kontinu dari kultur cair ke kultur padat. Pembuatan kultur cair pada dasarnya menggunakan media standar potato dextro broth dan atau sejenisnya, kemudian diinokulasikan jamur patogen serangga dan diletakkan pada orbital shaker selam 7 hari, kemudian setelah itu diinokulasikan pada kultur padat yang bisa berupa beras jagung atau beras menir dan atau limbah produk pertanian. Inkubasi selama 2 minggu kemudian dilakukan serial pengerian sampai kemudian didapatkan tepung murni miselia jamur dan dikemas.

Ada 2 produk yang telah diproduksi di laboratorium Agroteknologi Program Studi Agroteknologi Fakultas Pertanian Universitas Jember. 


\section{1. $\operatorname{METAR}^{\circledR}$}

Bahan aktif: Metarhizium anisopliae. Formulasi: Tepung murni miselia jamur. Berat/Sachet: 100 gram.

Serangga sasaran: wereng, uret, ulat tanah, belalang kembara.

Rekomendasi: larutkan $1 / 2$ sachet ke dalam tangki sprayer berisi 14-15 liter, kemudian bisa disemprotkan di atas daun dimana serangga target berada atau kurangi tekanan nozzle kemudian semprotkan (kocorkan) ke permukaan tanah untuk hama yang hidup dalam tanah.

2. BEBAS $^{\circledR}$

Bahan aktif: Beauveria bassiana. Formulasi: Tepung murni miselia jamur. Berat/Sachet: 100 gram.

Serangga sasaran: wereng, walang sangit, penggerek buah kopi, Helopeltis anthonii, uret, ulat tanah, hama gudang.

Rekomendasi: larutkan $1 \frac{1}{2}$ sachet ke dalam tangki sprayer berisi 14-15 liter, kemudian bisa disemprotkan di atas daun dimana serangga target berada atau kurangi tekanan nozzle kemudian semprotkan (kocorkan) ke permukaan tanah untuk hama yang hidup dalam tanah.

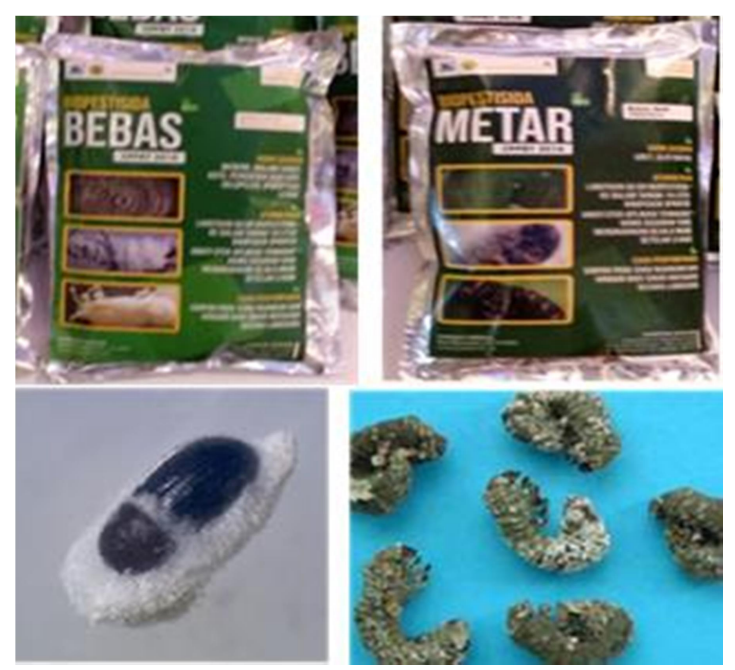

Gambar 1.

Prototipe biopestisida berbahan aktif jamur patogen serangga (atas) dan hasil aplikasi cendawan Beauveria bassiana; Keserangga Penggerek buah kopi (PBKO) (kiri bawah) serta hasil aplikasi cendawan Metarhizium anisopliae Keserangga uret tebu (kanan bawah).

\section{Dampak Ekonomi dan Sosial}

\begin{tabular}{|c|c|c|c|c|}
\hline $\begin{array}{c}\text { KEY } \\
\text { PARTNERS }\end{array}$ & KEY ACTIVITIES & $\begin{array}{c}\text { VALUE } \\
\text { PROPOSITION }\end{array}$ & $\begin{array}{c}\text { CUSTOMER } \\
\text { RELATIONSHIP }\end{array}$ & $\begin{array}{l}\text { CUSTOMER } \\
\text { SEGMENTS }\end{array}$ \\
\hline $\begin{array}{l}\text { Aliansi Startagis : } \\
\text { dengan kelompok } \\
\text { produsen } \\
\text { SAPRODI } \\
\text { pertanian } \\
\text { Supplier } \\
\text { Relationship: } \\
\text { menitipkan produk } \\
\text { pada } \\
\text { agen/took/kios } \\
\text { SAPRODI }\end{array}$ & $\begin{array}{l}\text { Formulasi Biopest } \\
\text { Granular Berbahan } \\
\text { Aktif Jamur } \\
\text { Entomopatogen } \\
\text { Produksi massal } \\
\text { bentuk biopest } \\
\text { granula } \\
\text { Platform Produk } \\
\text { Unggulan dengan } \\
\text { HAKI }\end{array}$ & $\begin{array}{l}\text { Biopestisida } \\
\text { Formulasi Granular } \\
\text { Berbahan Aktif } \\
\text { Jamur } \\
\text { Entomopatogen : } \\
\text { efektif menurunkan } \\
\text { serangan hama uret } \\
\text { sebesar 70-90\%, aman, } \\
\text { ramah lingkungan dan } \\
\text { manjur untuk tanaman } \\
\text { pangan dan } \\
\text { hortikultura }\end{array}$ & $\begin{array}{l}\text { Mengembangkan Model } \\
\text { Sekolah Lapangan HPT } \\
\text { untuk penerapan } \\
\text { BIOPEST. } \\
\text { Demoplot bersama } \\
\text { kelompok } \\
\text { Tani/Pengusaha } \\
\text { Pertanian dan } \\
\text { Perkebunan dan } \\
\text { pengembangannya. } \\
\text { Pemgembangan } \\
\text { kelompok usaha } \\
\text { pertanian ramah } \\
\text { lingkungan/organic } \\
\text { (gerakan goo green) }\end{array}$ & $\begin{array}{l}\text { Kelompok Tani dan } \\
\text { Petani : Hortikultura, } \\
\text { tanaman pangan, dan } \\
\text { tanaman perkebunan } \\
\text { Perusahaan berbasis } \\
\text { pertanian dan } \\
\text { perkebunan } \\
\text { Kelompok pengusaha } \\
\text { pertanian organic dan } \\
\text { derivasinya }\end{array}$ \\
\hline
\end{tabular}




\begin{tabular}{|c|c|c|c|}
\hline KEY RESOURCES & \multirow[b]{2}{*}{$\begin{array}{l}\text { Biopestisida } \\
\text { Formulasi Granular } \\
\text { Berbahan Aktif } \\
\text { Jamur } \\
\text { Entomopatogen ber } \\
\text { HAKI : aspek jaminan } \\
\text { mutu produk secara } \\
\text { akademis }\end{array}$} & CHANELS & \\
\hline $\begin{array}{l}\text { Asset Fisik: Bangunan } \\
\text { pabrik, fasilitas } \\
\text { produksi, mesin } \\
\text { produksi } \\
\text { Asset Intelektual : } \\
\text { Hak Cipta (HAKI) } \\
\text { Biopest Granula Jamur } \\
\text { Entomopatogen } \\
\text { Finansial: Modal } \\
\text { pengembangan dan } \\
\text { produksi sebesar Rp. } \\
\text { 153.000.000 }\end{array}$ & & $\begin{array}{l}\text { Awarenwess : } \\
\text { optimalisasi teknologi IT } \\
\text { dan SOSMED } \\
\text { Indirect : Model } \\
\text { konsinyasi dengan } \\
\text { agen/took SAPRODI } \\
\text { Direct :Penjulan } \\
\text { langsung kepada } \\
\text { kelompok tani/petani/ } \\
\text { pengusaha perkebunan }\end{array}$ & \\
\hline \multicolumn{2}{|l|}{ COST STRUCTURE } & \multicolumn{2}{|c|}{ REVENUE STREAMS } \\
\hline \multicolumn{2}{|c|}{$\begin{array}{l}\text { Biaya Tetap (BIaya penyusutan asset, bunga modal, dan Pajak) : } \\
\text { Rp. } 25.600 .000 \text { per tahun atau setara Rp. } 853,30 \text { per kg atau Rp. } 85,3 \\
\text { per Sachet . } \\
\text { Biaya Variabel (Bahan baku, air, listrik, upah tenaga kerja, } \\
\text { salesman, tranportasi, perawatan dan perbaikan instalasi) : Rp. } \\
38.050 \text { per kg atau sachet Rp. } 3.805 \text { per Sachet. }\end{array}$} & \multicolumn{2}{|c|}{$\begin{array}{l}\text { Nilai Penjualasan per sachet } @ 100 \text { Gram = Rp. } \\
5.000 \\
\text { Harga Pokok Penjualan = Rp. } 3.890 \text { per sachet } \\
\text { Keuntungan per sachet = Rp. } 1.110,- \\
\text { Jumlah Produksi Tahun } \mathrm{I}=100 \mathrm{~kg} \text { per hari }(1000 \\
\text { sachet) x } 300 \text { hari per tahun = } 300.000 \\
\text { sachet/Tahun } \\
\text { Net Benefit = Rp. } 333.000 .000 \text { per tahun }\end{array}$} \\
\hline
\end{tabular}

\section{KESIMPULAN DAN SARAN}

\section{Kesimpulan}

Produksi biopestisida jamur patogen serangga di UPT Agroteknopark telah berjalan sesuai dengan rencana kegiatan yang akan diakselerasi skala produksinya. Akselerasi pemasaran dilaksanakan dengan berbagai cara yaitu melalui pembuatan website, instagram dan memperluas jejaring ke masyarakat melalui jejaring kelompok tani dan program KKN.

\section{Saran}

Perlu adanya penyempurnaan prototipe dengan melakukan demo plot dengan mengukur indikator efektivitas untuk mengendalikan OPT minimal ke 2 desa mitra. 


\section{Daftar Pustaka}

Anonim. 2011. Masterplan Percepatan dan Perluasan Pembangunan Ekonomi Indonesia, Jakarta: Kementerian Koordinator Bidang Perekonomian.

Badan Pusat Statistik (BPS) (2013). Statistik Tanaman Pangan, Biro Statistik Indonesia.

Suryana, A. 2011. Kebijakan non produksi untuk antisipasi fluktuasi pasokan dan harga pangan global mendukung ketahanan pangan nasional, Lokakarya: Antisipasi Dampak Perubahan Iklim dan Krisis Pangan dalam Upaya Memantapkan Ketahanan Pangan, 4 April 2011, Jakarta.

Borror, Triplehorn, dan Johnson. 1992. Serangga (Edisi ke enam). Yogyakarta: Gadjah Mada University Press.

Budianto D. 2003. Kebijaksanaan penelitian dan pengembangan teknologi peningkatan produktivitas padi terpadu di Indonesia. Prosiding Lokakarya pelaksanaan program peningkatan Produktivitas Padi Terpadu (P3T). Puslitbangtan. Bogor.

Burges, H.D., (Ed.). 1998. Formulation of Microbial Biopesticides. (pp. 7-27). Dodrecht, The Netherlands: Kluwer Academic Publisher. Mollet, 2001Ditjenbun, 2010. Pengenalan dan Pengendalian Hama Uret (Lepidiota stigma F.) Pada Tebu. Direktorat Perlindungan Perkebunan Direktorat Jenderal Perkebunan Kementerian Pertanian.

Chandler, D., Bailey, A., Tatchell, G.M., Davidson, G., Greaves, J., \& Grant, W.P. 2011. The Development, Regulation and Use of Biopesticides for Integrated Pest Management. Philosophical Transaction of The Royal Society B, 386, 2-13Kalshoven, L.G.E. 1981. Pest of Crop in Indonesia. Revised by Van Der Laan, PT Ikhtiar Baru, Van Hooven. Jakarta.

Deshpande MV. Formulations and applications of mycopathogens. In: Rabindra RJ,Hussaini SS, Ramanujam B, editors. Microbial biopesticide formulations and application. Bangalore, India: PDBC; 2005. p. .150-8.. Tech. Document No. 55.

Gašić S. and Tanović B. 2013, Biopesticide Formulations, Possibility of Application and Future Trends, Pestic. Phytomed. (Belgrade), 28(2), 97-102.

Kulkarni M., 2008. Development of Myrothecium verrucaria as a mycopesticide for the control of plant pathogenic fungi and insects. Thesis, University of Pune, Pune, India.

Mollet, H., \& Grubenmann, A. 2001. Formulation technology. (pp. 389-397). Weinheim, Germany: Wiley-VCH Verlag. Gasic \& Tanovic 2013.

Purnomo. 2010. Pengantar Pengendalian Hayati, Penerbit andy Yogyakarta 22. 